\title{
Chromosome instability in the murine melanoma cell line K-1735 is due to drug-specific mechanisms
}

\author{
Margit A. Nemeth, T.C. Hsu and S. Pathak
}

\begin{abstract}
The purpose of the present study was to investigate chromosomal instability and DNA repair by exposing clones from the murine melanoma cell line K-1735 to the radiomimetic drug bleomycin and to the DNA polymerase $\alpha$ inhibitor aphidicolin. Results from previous experiments conducted with human lymphocytes have suggested synergistic chromosomal damage after simultaneous exposure to these two agents. However, in the murine cell line studied here, there was no direct correlation between the effects of these two agents. Indeed, the extensive variation in the responses to aphidicolin and bleomycin suggested different mechanisms for the repair of bleomycin-induced DNA damage by the clones. Evaluation of the unexplained propensity of some bleomycin-treated metaphase cells to disintegrate suggested that this phenomenon was most likely the result of a direct action of bleomycin, rather than a potential manifestation of tumor cell instability.
\end{abstract}

\section{INTRODUCTION}

Considerable evidence supports the popularly accepted tenet that tumors are composed of a heterogeneous population of cells, a few of which acquire traits that lead to more aggressive and metastatic behavior. Cytogenetic data have shown that tumor cells are genetically more unstable than normal cells (Nowell, 1974, 1976, 1986), and therefore are inherently more likely to acquire aberrations that can lead to increasingly aggressive behavior (Pathak, 1990). This genetic instability or propensity for DNA damage may be inherited or acquired, or may occur by a combination of both of these mechanisms.

Inherent chromosomal instability was first described in various chromosomal breakage syndromes, including Bloom's syndrome, Fanconi's anemia, ataxia telangiectasia, and xeroderma pigmentosum (Hecht and McCaw, 1977; Setlow, 1978; German, 1980). Patients with these syndromes exhibit a much higher rate of spontaneous or induced chromosomal aberrations than normal individuals and are predisposed to certain types of neoplasias. Although these syndromes are extreme examples of this phenomenon, variations in chromosomal instability (as represented by mutagen-induced DNA damage) have been found in the population as a whole (Hsu, 1983). Thus, individuals with a high frequency of spontaneous or induced chromosomal breaks will also have a high genetic mutation rate and, hence, a greater susceptibility for neoplasia.

Hsu (1983) proposed a protocol for the use of sensitivity to mutagens (chromosome instability) as a biological marker for susceptibility to carcinogens. Treating peripheral blood lymphocytes with the radiomimetic agent bleomycin reveals differences in this sensitivity and within a population, and this is the basis for an assay in which the number of chromosomal breaks per cell is determined after exposure to the mutagen (Hsu et al., 1986, 1990). The average number of breaks per cell (b/c) is then used to predict an individual's susceptibility to environmental carcinogens.

In recent years, more than 2,000 blood samples from normal individuals and a variety of cancer patients have been studied in this laboratory. The mean induced chromatid b/c frequency for normal individuals is generally low (below 0.06 ), whereas in a large number of cancer patients, the frequency exceeds 1.00 . However, in cultures of lymphocytes from cancer patients and normal individuals, a small percentage (less than $1 \%$ ) of metaphases may have partially or totally disintegrated chromosomes. These aberrant cells supposedly represent somatic mutants in which the capability for DNA repair is severely reduced or absent.

In this work, bleomycin assays and concomitant treatment with bleomycin and aphidicolin were used to investigate chromosomal instability and its relationship to tumorigenicity and metastasis (Nemeth et al., 1997) in the murine parental cell line K-1735 and a panel of newly isolated clones. In particular, the correlation between the $\mathrm{b} / \mathrm{c}$ values and chromosome dissolution and between chromosome dissolution and metastasis was examined.

\section{MATERIAL AND METHODS}

$$
\text { K-1735 cell line }
$$

The original K-1735 melanoma was induced in a C3H/ HeN mouse by exposure to ultraviolet (UV) light followed 
by painting with croton oil (Kripke, 1979). An early passage of the cell line was kindly provided by Dr. Isaiah J. Fidler (Department of Cancer Biology, The University of Texas M.D. Anderson Cancer Center, Houston, TX). All tumor cells were maintained in RPMI-1640 culture medium supplemented with $10 \%$ fetal bovine serum (FBS). Antibiotics, other than those used for experimental purposes, were not added to the culture medium. The cultures were incubated at $37^{\circ} \mathrm{C}$ in a humidified incubator with $5 \% \mathrm{CO}_{2} / 95 \%$ air.

\section{Cell cloning}

Clones of the parental K-1735 cell line were isolated in vitro by placing $10 \mu \mathrm{l}$ of cell suspension containing 100 cells $/ \mathrm{ml}$ of RPMI medium with $10 \%$ FBS in alternate wells of a 96-well plate. The wells were then filled with medium and the cells allowed to settle for 6-8 h. Wells containing single cells were marked and monitored for continued growth. After a large colony had formed, the cells were dislodged using a $0.25 \%$ trypsin- $0.02 \%$ EDTA solution, transferred to increasingly larger well plates, and finally transferred to $25-\mathrm{cm}^{2}$ tissue culture flasks. Fifty-two clones (C1 to $\mathrm{C}-52$ ) were isolated and then screened for bleomycin sensitivity.

\section{Bleomycin experiments}

Individual clones and the parental K-1735 cell line were exposed to various concentrations of bleomycin (0.003-0.02 units $/ \mathrm{ml}$ ), depending on the experiment. Cultures were fed fresh medium approximately $24 \mathrm{~h}$ prior to the experiment, and those $70-90 \%$ confluent were treated with bleomycin for 3 or $5 \mathrm{~h}$. Bleomycin concentrations ranging from $0.0005-0.003$ units $/ \mathrm{ml}$ for 3 or $5 \mathrm{~h}$ were used to assess the chromatid break frequencies of the different clones. A minimum of 50 randomly selected metaphases was scored for chromatid breaks. Chromatid gaps, double minute fragments, and small unmatched centric chromosomes were not counted. Exposure times of $3 \mathrm{~h}$ were used to screen for disintegrated chromosome morphologies at higher bleomycin concentrations (0.01-0.02 units/ml). One hundred metaphases from each sample were analyzed for the presence of intact and disintegrated chromosomes. The extent of disintegration was not quantitated and if only a few chromosomes in a metaphase plate showed signs of disintegration, the plate was still scored as "disintegrated".

\section{Aphidicolin experiments}

Selected cultures were treated with aphidicolin alone or aphidicolin plus bleomycin for $3 \mathrm{~h}$. In all experiments, aphidicolin was first dissolved in ethanol and then added to the culture flasks to give a final concentration of $0.04 \mu \mathrm{M}$. The final percentage of ethanol per culture flask was $0.2 \%$, and control cultures were treated with ethanol alone or bleomycin plus ethanol.
Cell harvesting and chromosome preparation

Cell cultures were fed fresh medium $24 \mathrm{~h}$ before harvesting to stimulate mitotic activity. Thirty minutes before harvesting, Colcemid was added to each culture flask at a final concentration of $0.01 \mu \mathrm{g} / \mathrm{ml}$. Cultures $75-95 \%$ confluent were harvested by first rinsing the monolayer with serum-free RPMI-1640 and then covering the cells with a thin layer of $0.25 \%$ trypsin- $0.02 \%$ EDTA solution $(0.5 \mathrm{ml}$ per T2 5 flask) for $5-15 \mathrm{~min}$ at $37^{\circ} \mathrm{C}$, depending on the culture. The flask was then tapped sharply to dislodge the cells from the surface, and serum-supplemented medium was added to the flask to resuspend the cells and inactivate the trypsin. The medium was vigorously pipetted up and down to obtain a single-cell suspension. After centrifugation, the cell pellet was resuspended in $10 \mathrm{ml}$ of hypotonic solution $(0.06 \mathrm{M} \mathrm{KCl})$ for $15 \mathrm{~min}$ at room temperature and methanol:glacial acetic acid fixative (3:1 by volume) then added. After a further centrifugation, the pellet was washed twice with fixative, and air-dried slide preparations were made. The slides were stained with $4 \%$ Giemsa for $10 \mathrm{~min}$ and those samples to be karyotyped were Giemsa-banded as described previously (Pathak, 1976).

\section{Statistical analysis}

Statistical analyses of the data were conducted using Minitab statistical software (release 8.2, Minitab Inc., State College, PA), and Instat software (version 1.15, GraphPad Software, San Diego, CA). Linear regression analysis was performed on both the break per cell and mitotic index data for the initial bleomycin concentration experiments on the parental K-1735 cell line, in order to verify the effect of increasing bleomycin concentrations on these two variables. To determine the lowest bleomycin concentration at which a statistically significant number of breaks could be observed, the repeated measure analysis of variance (ANOVA) test was used.

\section{RESULTS}

The clones isolated from the parental K-1735 cell line were screened for sensitivity to bleomycin and the 10 most sensitive and resistant clones were chosen for further analysis. Of these 10, only seven are represented in the final data. One clone (C-27) was excluded because it was extraordinarily unstable, giving inconsistent data; a second, initially highly sensitive, clone (C-23) became less sensitive over time, and a third clone (C-34) gave results similar to another clone in the study and was therefore discarded on the basis of redundancy.

\section{Bleomycin experiments}

Several dose-response curves were generated for the parental K-1735 cell line using bleomycin concentrations 
ranging from 0.005 to 0.03 units $/ \mathrm{ml}$. Figure $1 \mathrm{~A}$ shows the increase in $\mathrm{b} / \mathrm{c}$ values with increasing bleomycin concentrations. Figure 1B illustrates the corresponding decrease in mitotic index. One hundred metaphases were screened at five different bleomycin concentrations and the condition of the metaphases was ranked as shown in Figure 2. At very low concentrations of bleomycin $(0.003$ units $/ \mathrm{ml})$, $90 \%$ of the cells had less than $12 \mathrm{~b} / \mathrm{c}$ and less than $1 \%$ were disintegrated. The number of metaphases with more than $12 \mathrm{~b} / \mathrm{c}$ rose with increasing bleomycin concentration. At 0.02 units of bleomycin $/ \mathrm{ml}$, a plateau was reached, with approximately $75 \%$ of the cells showing more than $12 \mathrm{~b} / \mathrm{c}$, $15 \%$ having less than $12 \mathrm{~b} / \mathrm{c}$, and $10 \%$ in a stage of disintegration. Figure 3 shows a series of metaphases with progressive chromosomal disintegration.

A standard concentration of 0.001 units of bleomycin/ $\mathrm{ml}$ was chosen for several reasons: 1) this was the lowest bleomycin concentration at which a significant increase $(\mathrm{P}$ $=0.0134)$ in $\mathrm{b} / \mathrm{c}$ values was evident, 2 ) at this concentration, the initial bleomycin damage was minimal (but still caused a detectable variation in the response) and did not mask the effects of aphidicolin in clones treated simultaneously with bleomycin and aphidicolin, and 3) at this concentration, most of the cells had fewer than $12 \mathrm{~b} / \mathrm{c}$ and the number of cells with disintegrated chromosomes was not significant. After this initial screening, the selected clones were treated with different bleomycin concentrations for different times to determine the range of responses. The variation in sensitivity among the individual clones remained constant with increasing bleomycin concentrations; the least sensitive clone was always clone $\mathrm{C}-2$, and the most sensitive was $\mathrm{C}-26$, regardless of the bleomycin concentration. The results for the $3 \mathrm{~h}$ and $5 \mathrm{~h}$ treatments with a fixed concentration of bleomycin showed some variation in response. Two clones, C-19 and C-40, showed a dramatic increase in sensitivity when the treatment time increased from the $3 \mathrm{~h}$ to $5 \mathrm{~h}$ (Figure 4; one-way ANOVA: $\mathrm{P}=0.0069$ for $\mathrm{C}$ 19 , and $\mathrm{P}=0.0468$ for $\mathrm{C}-40$ ). One explanation for these results is that the cells with the highest degree of bleomycin damage may stall in the $\mathrm{G} 2$ phase of the cell cycle and the damage may not be evident in the 3-h readings. Only after 5 $\mathrm{h}$ do these cells enter mitosis, and the damage is then reflected in the metaphase cells. Because of the need to minimize damage before the aphidicolin experiments, all subsequent exposures to bleomycin were for $3 \mathrm{~h}$.

\section{Aphidicolin experiments}

All of the selected clones were treated with aphidicolin alone or with aphidicolin and bleomycin. The treatment time was limited to $3 \mathrm{~h}$ because a 5 -h treatment with both substances resulted in too much damage to the cells, making it difficult to assess the different responses of the clones. The results of these experiments are summarized in Figure 5. Contrary to the findings reported for human lymphocytes (Hsu et al., 1986), this murine system showed

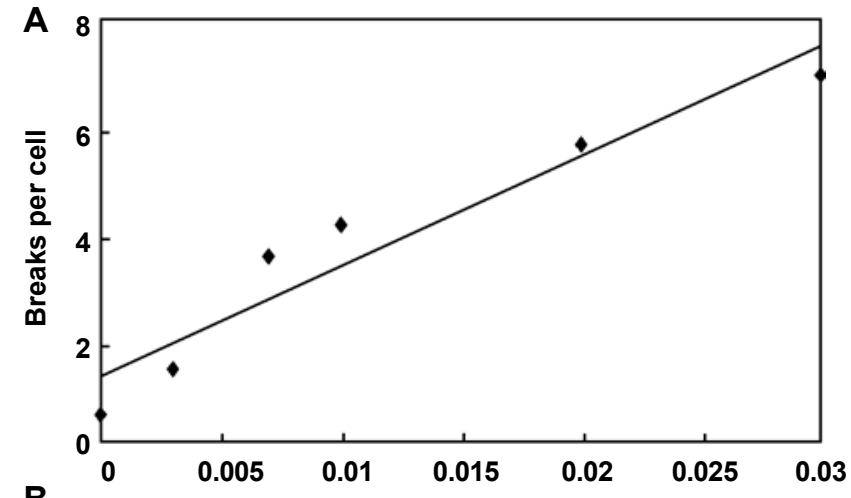

B

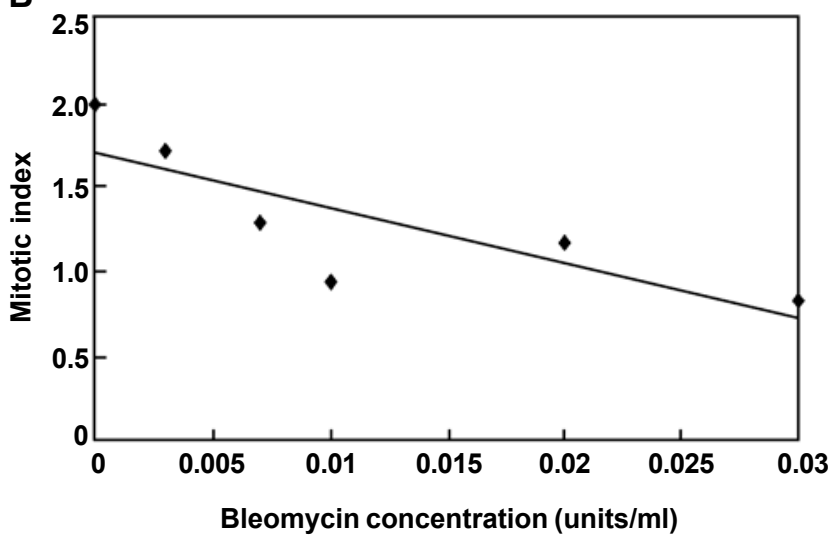

Figure 1 - The frequency of chromatid breaks (A) and mitotic index (B) in murine melanoma parental K-1735 cells treated with bleomycin for $5 \mathrm{~h}$. In $A$ the average number of breaks per cell rose with increasing bleomycin concentrations $(\mathrm{P}=0.0028, \mathrm{r}=0.9566)$, whereas in $\mathrm{B}$, the mitotic index decreased over the same concentration range $(P=0.0462, r=0.8190)$. The points are the means of 50 cells.

no direct correlation between bleomycin and aphidicolin sensitivities (one-way ANOVA). The reaction of the clones to bleomycin with or without aphidicolin emphasized the heterogeneity within a tumor cell line. Concurrent treatment of clones C-2 and C-48 with bleomycin and aphidicolin resulted in an additive effect of the two agents (Figure 5). The damage induced by simultaneous treatment in clone $\mathrm{C}-39$ appeared to be caused primarily by aphidicolin. The other clones showed no significant increase in the $\mathrm{b} / \mathrm{c}$ values compared to baseline bleomycin results when treated simultaneously with aphidicolin. Control cultures treated with $0.2 \%$ ethanol or bleomycin plus $0.2 \%$ ethanol showed no significant increase in their $\mathrm{b} / \mathrm{c}$ values compared with untreated and bleomycin-treated samples, respectively (Student's paired $t$-test, $\mathrm{P}=0.092$ for untreated and $\mathrm{P}=$ 0.118 for bleomycin-treated cultures).

\section{Chromosomal disintegration}

As the concentration of bleomycin increased, the number of metaphase spreads with a disintegrated chromosomal morphology also increased noticeably (Figure 3). 


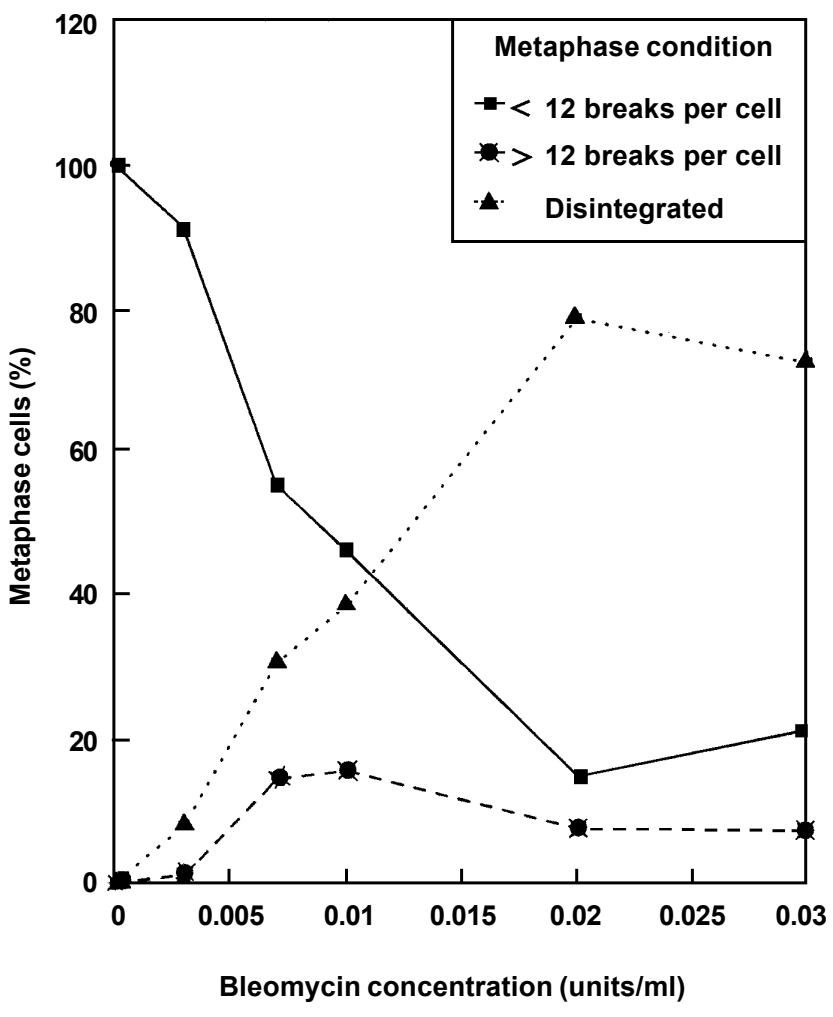

Figure 2 - The metaphase condition of parental K-1735 cells treated with increasing concentrations of bleomycin for $5 \mathrm{~h}$. One hundred metaphases were screened at each concentration of bleomycin. Graph illustrates percent metaphases with less than $12 \mathrm{~b} / \mathrm{c}$ (solid line); percent metaphases with more than $12 \mathrm{~b} / \mathrm{c}$ (dotted line), and percent metaphases with disintegrated morphology (dashed line).

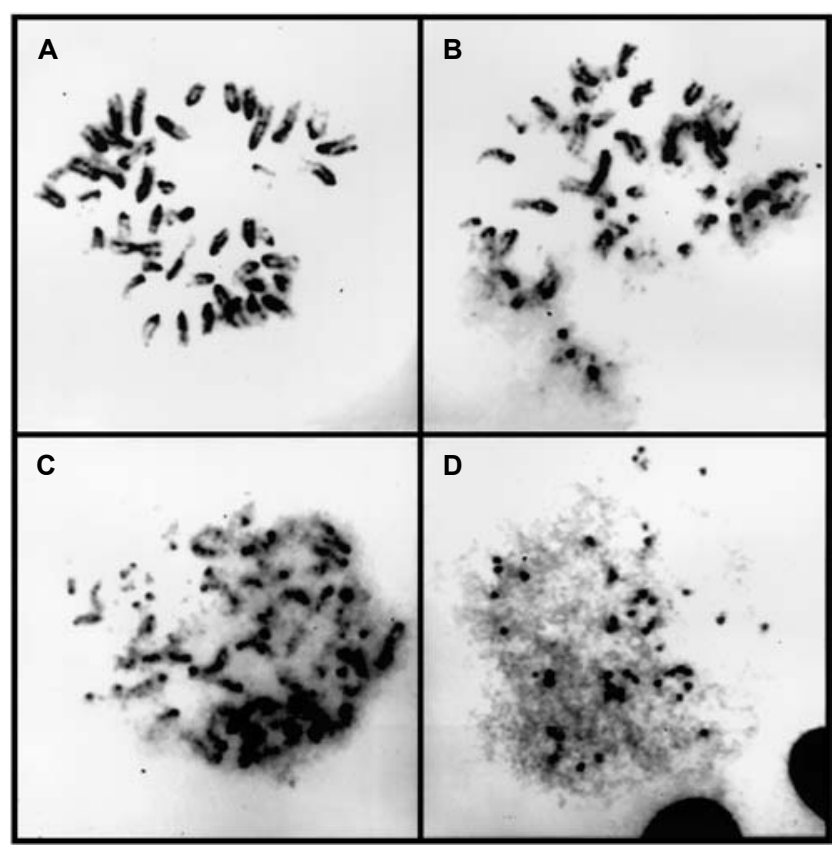

Figure 3 - Bleomycin-treated, Giemsa-stained K-1735 cells showing the initiated (A), intermediate (B and C) and final (D) stages of chromosomal disintegration. Some condensed heterochromatin is still visible in the last stage.
At higher bleomycin concentrations, the stages of disintegration were also readily apparent. Figure 3 shows the early (A), intermediate (B and C), and late (D) stages of chromosomal disintegration. The breakdown of chromosomal morphology began at the telomeric ends and progressed toward the centromeres. In the late stages of disintegration, only very small fragments of heterochromatin remained. This progression of chromosomal dissolution was the same as previously seen in bleomycin-treated human peripheral blood lymphocytes.

In clones treated with high concentrations of bleomycin $(0.01 \mathrm{units} / \mathrm{ml}$, which is 10 times the standard assay concentration), the percentage of metaphase cells with some degree of dissolution ranged from 10 to $60 \%$. There was no correlation between the sensitivity to bleomycin and the percentage of disintegrated metaphases (regression analysis, $\mathrm{P}>0.05$ ). Figure 6 shows the percentage of disintegrated metaphases for the seven clones treated with 0.01 units of bleomycin/ml for $3 \mathrm{~h}$.

\section{DISCUSSION}

Bleomycin induces chromosomal damage, including chromatid gaps, breaks and translocations, whereas aphidicolin specifically inhibits DNA polymerase $\alpha$ (Paika and Krishan, 1973; Cherry and Hsu, 1983; Hsu et al., 1990). Simultaneous treatment of cell cultures with these two agents provides a means of determining the role of DNA polymerase $\alpha$ in the repair of bleomycin-induced DNA damage. In this study, we examined the heterogeneity of the capacity for DNA repair in tumor cells and assessed whether the variation in sensitivity to bleomycin was a direct result of differences in DNA polymerase $\alpha$ activity (Bender and Preston, 1982; Bender, 1995).

The sensitivity of the clones to bleomycin varied considerably. Following an initial screening, several clones representing the entire range of bleomycin sensitivities were chosen for further analysis. The clones that were resistant to bleomycin gave consistent breaks/cell (b/c) results, and proved to be very stable over time. Three highly sensitive clones with $\mathrm{b} / \mathrm{c}$ values greater than 1.5 were very unstable and had variable b/c values in repeated experiments, but became more resistant over time. As a result, it was difficult to isolate a clone with a sustained sensitivity greater than $1.5 \mathrm{~b} / \mathrm{c}$. One possible explanation for the increased instability associated with these highly sensitive clones is that their spontaneous break frequencies were also high such that those cells with the most spontaneously induced DNA damage were dying while the more stable cells continued to grow. As a result, although several clones had higher initial b/c values, clone C-26 (approximately $1.5 \mathrm{~b} /$ c) was the most sensitive clone that gave consistent bleomycin readings over time. Another explanation could be that these sensitive clones had lost a considerable amount of their telomeric DNA (Pathak et al., 1994a,b). Clone C26 also had a low spontaneous chromatid breakage rate. 


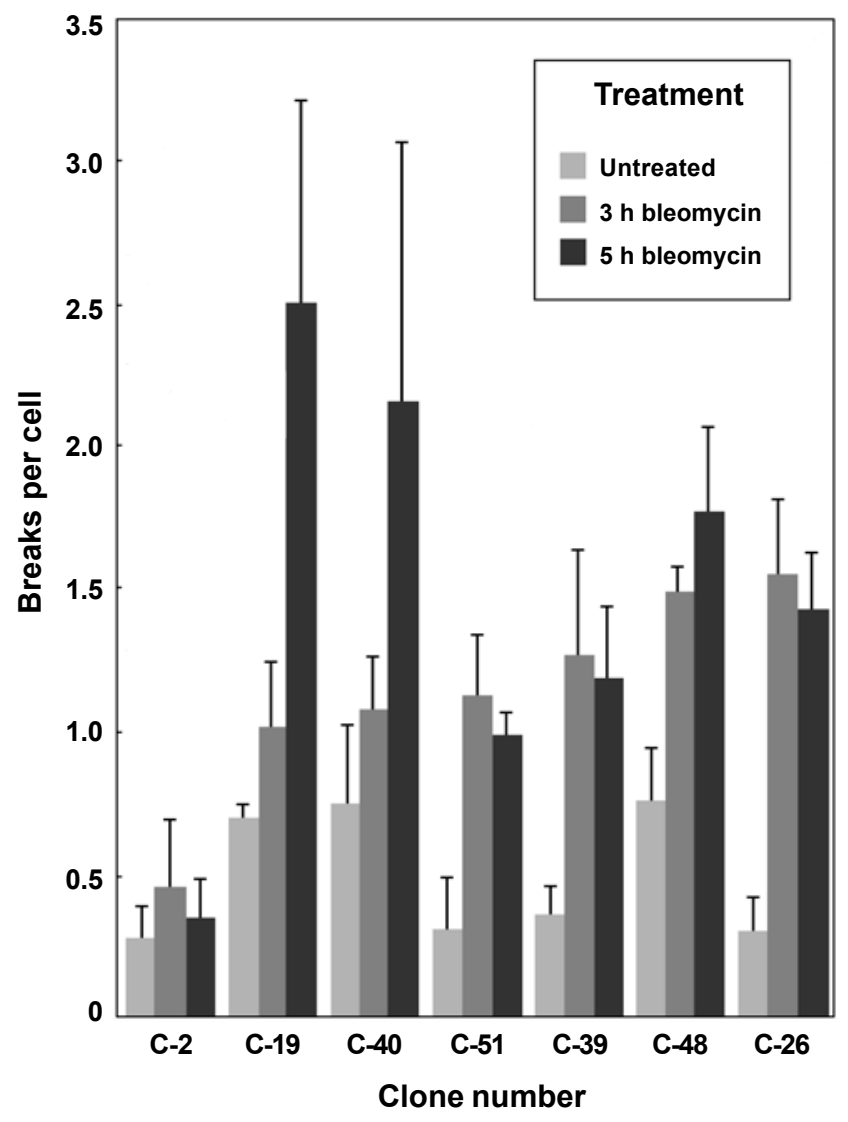

Figure 4 - Breaks per cell for seven K-1735 clones treated with bleomycin $(0.001$ units $/ \mathrm{ml})$ for $3 \mathrm{~h}$ and $5 \mathrm{~h}(\mathrm{n}=3$, mean $+1 \mathrm{SD})$.

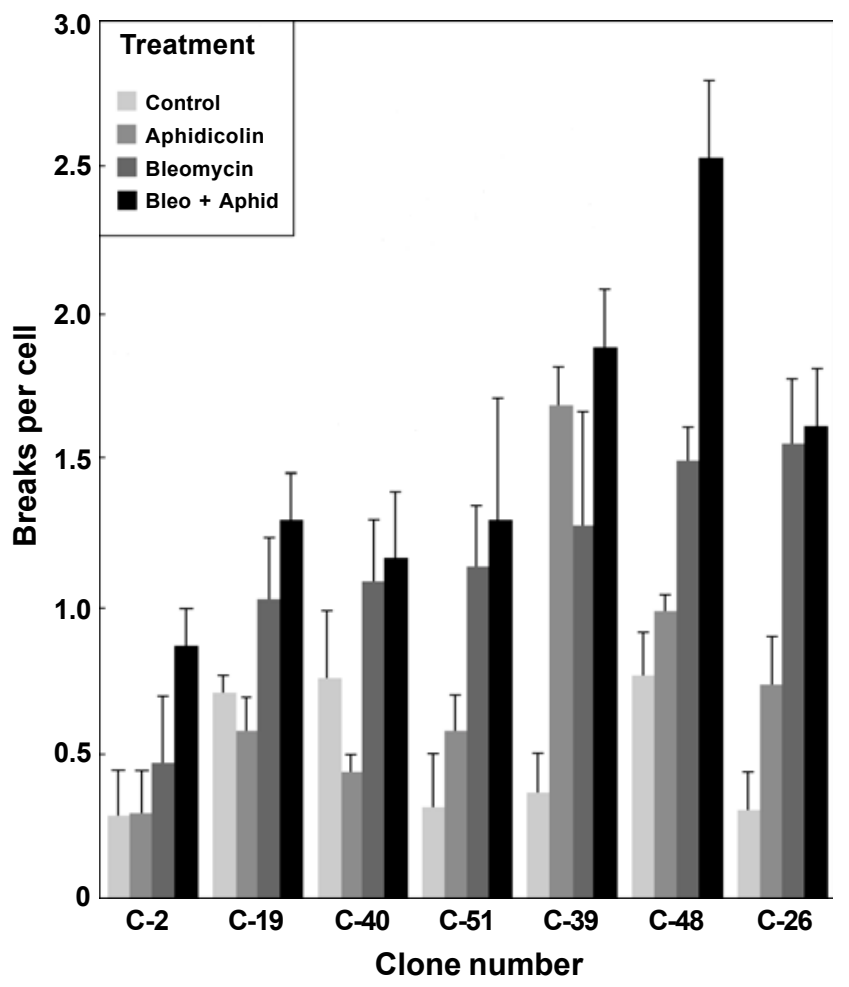

Consequently, the initial bleomycin screening of this clone was repeated six times to verify the reliability of the data.

The aphidicolin experiments showed no correlation with bleomycin sensitivity or with the results of simultaneous treatment with both bleomycin and aphidicolin. Contrary to previous findings (Hsu et al., 1986), these results showed no synergistic effect between bleomycin and aphidicolin in inducing DNA damage. This finding suggested that in the murine system, several mechanisms may be involved in the repair of bleomycin-induced DNA damage, and that DNA polymerase $\alpha$ is not necessarily the primary repair mechanism in these cells.

Chromosomal disintegration, a unique response of metaphase chromosomes to bleomycin, was originally observed by Kuo and Hsu (1978) in Chinese hamster ovary and cactus mouse (Peromyscus eremicus) cell cultures. Various degrees of disintegration were seen with extended treatment $(5 \mathrm{~h}$ and $7 \mathrm{~h}$ ) at a high concentration of bleomycin $(0.05$ units $/ \mathrm{ml})$. Although these investigators reported no evidence of chromosomal disintegration after shorter exposure times or lower concentrations, it is possible that disintegration did occur, but at a much lower frequency.

Chromosomal disintegration in the K-1735 parental cell line was seen at bleomycin concentrations of 0.003 $0.03 \mathrm{units} / \mathrm{ml}$ and exposure times of $3 \mathrm{~h}$ and $5 \mathrm{~h}$. No evidence of chromosomal disintegration was found in untreated controls or samples treated with aphidicolin alone (data not shown). In clones with different sensitivities to bleomycin (as measured by the b/c at low drug doses), which were treated with high concentrations of bleomycin $(0.01$, 0.015 , and 0.02 units $/ \mathrm{ml}$ ) and scored for the percentage of metaphases showing a disintegrated chromosomal morphology, there was no correlation between sensitivity to bleomycin and the propensity to disintegrate. These results suggest that the two phenomena have different mechanisms.

The parental K-1735 cell line is a heterogeneous population of cells (Pathak et al., 1991), consisting of two sub populations, one with optimal and the other with amplified amounts of telomeric DNA (Multani et al., 1999b). A continuous increase in the percentage of disintegrated metaphases was seen in parental K-1735 cells with increasing bleomycin concentration. However, for each clone screened at increasing bleomycin concentrations, no significant increase in the percentage of metaphases with disintegrated chromosome morphology was apparent. These results suggest that the propensity of a particular group of cells to undergo chromosomal dissolution varies depending on the drug concentration used.

The mechanism by which disintegration occurs is still unclear. Extensive DNA strand breakage in the nucleosome

Figure 5 - Breaks per cell for seven K-1735 clones treated with aphidicolin $(0.04 \mu \mathrm{M})$, bleomycin $(0.001 \mathrm{units} / \mathrm{ml})$, or both agents concurrently for $3 \mathrm{~h}$. The clones are listed in order of increasing sensitivity to bleomycin $(n=3$, mean $+1 \mathrm{SD})$. 


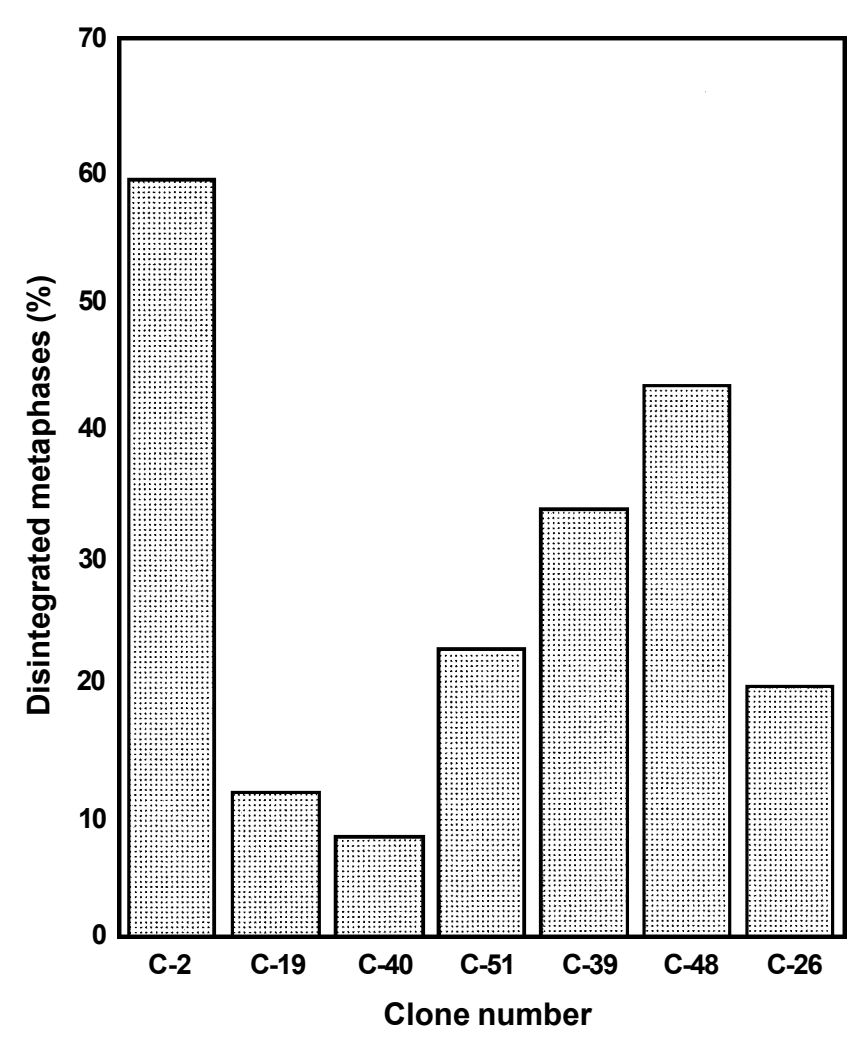

Figure 6 - Percentage of metaphases with disintegrated chromosomal morphologies in seven K-1735 clones treated with bleomycin ( 0.01 units/ $\mathrm{ml}$ ) for $3 \mathrm{~h}$. One hundred metaphases were analyzed from each clone. The clones are listed in order of increasing sensitivity to bleomycin.

linker regions or extensive loss of telomeres may be responsible for the "dissolved" chromosomal morphology (Multani et al., 1999a,b). By inducing breaks specifically in the linker regions, bleomycin may cause collapse of the chromatin structure (Kuo and Hsu, 1978). This suggestion agrees with the finding that disintegration begins at the telomeric ends of the chromosomes and progresses toward the centromeres. In the late stages of disintegration, the centromeric heterochromatin is all that remains amidst a mass of fragmented DNA. The centromeres are highly condensed and contain proteins that shield this region of DNA from the destructive effects of bleomycin. Although such a mechanism of disintegration is plausible, the actual cause of disintegration remains unexplained. Why do some cells disintegrate while others show very little damage as a result of bleomycin treatment? Do some cells have deficient DNA repair capabilities (possibly DNA polymerase $\alpha$ ), or do they lack protective mechanisms against the oxidative damage typically induced by bleomycin? It is possible that as clonal expansion occurs, aberrant cells with a severely diminished or completely absent DNA repair capability may arise. Without exposure to mutagens, such cells can survive, but once exposed to mutagens (ionizing radiation or radiomimetic chemicals), extensive chromosome/chromatid damage is left unrepaired. This scenario assumes that most or all of the cells exposed to bleomycin undergo the extensive DNA damage characteristic of chromosomal dissolution, but that only cells with a deficient ability to repair DNA actually disintegrate. More likely, these aberrant cells lack the biological mechanisms to protect them from oxidative damage in the first place. Thus, even though the cells may have adequate DNA repair mechanisms, the original bleomycin-induced damage is so extensive that it is unrepairable, and the chromatin structure collapses.

Inherent genetic instability can be studied at the singlechromosome level (Pai et al., 1999). Extensive analysis of the seven clones revealed inherent chromosomal fragility, with some chromosomes, such as chromosomes 1 (C-26 and C-48) and 14 (all clones), more likely to be involved in translocations, than others. C-2, the most bleomycinresistant clone, had some unique chromosomal anomalies which may contribute to its stability. Thus, $\mathrm{C}-2$ was the only clone not to contain an $\mathrm{Rb}(14 ; 14)$ (marker M3), previously associated with metastasis and aggressive growth characteristics (Pathak et al., 1991, 1995). C-2 was also the only clone to have an $\operatorname{Rb}(3 ; 3)$ which may contribute to its increased stability. Clone C-51 showed the greatest variability in karyotype and also contained two unique markers, $\mathrm{t}(15,16)$ and $\operatorname{dup}(\mathrm{X})$ (Nemeth et al., 1997). However, this clone had mid-range values for sensitivity to bleomycin and for the percentage of disintegrated metaphases, and showed no unusual response to aphidicolin. Since the performance of C-51 in these studies was unremarkable, the effects of these additional chromosomal anomalies were difficult to assess.

\section{ACKNOWLEDGMENTS}

Research supported in part by a grant from the Summerfield G. Robert Foundation of Dallas, a generous donation from Miss Kiki Cullum, the Institutional Prostate Cancer Research Program, and NIH grant RRO 499901. The authors thank Joyce Benjamin for expert secretarial assistance and Kathryn Carnes for editorial comments.

\section{RESUMO}

O objetivo do presente estudo foi investigar a instabilidade cromossômica e o reparo de DNA, expondo clones da linhagem celular de melanoma murino K-1735 à droga radiomimética bleomicina e ao inibidor da DNA polimerase $\alpha$, afidicolina. Resultados de experimentos anteriores realizados com linfócitos humanos sugeriram dano cromossômico sinergístico após exposição simultânea a esses dois agentes. Contudo, na linhagem celular murina aqui estudada, não houve correlação direta entre os efeitos desses dois agentes. De fato, a extensa variação nas respostas a afidicolina e bleomicina sugeriu diferentes mecanismos empregados pelos clones para o reparo de danos de DNA induzidos por bleomicina. A avaliação da propensão não explicada de algumas células metafásicas tratadas com bleomicina a se desintegrar sugere que este fenômeno foi mais provavelmente $o$ resultado de uma ação direta da bleomicina e não uma potencial manifestação de instabilidade de células tumorais. 


\section{REFERENCES}

Bender, M.A. (1985). Role of DNA polymerase a in chromosomal aberration production by ionizing radiation. Ann. N.Y. Acad. Sci. 459: 245-254.

Bender, M.A. and Preston, R.J. (1982). Role of base damage in aberration formation: interaction of aphidicolin and X-rays. Prog. Mutat. Res. 4: $37-46$.

Cherry, L.M. and Hsu, T.C. (1983). Bleomycin-induced chromosome damage in lympocytes of medullary thyroid carcinoma patients and their family members. Anticancer Res. 3: 367-372.

German, J. (1980). Chromosome-breakage syndromes: different genes, different treatments, different cancers. In: DNA Repair and Mutagenesis in Eukaryotes (Generoso, W.M., Shelby, M.D. and de Serress, F.J., eds.). Plenum Press, New York, pp. 429-439.

Hecht, F. and McCaw, B.K. (1977). Chromosome instability syndrome. Prog Cancer Res. Ther. (Genet. Hum. Cancer) 3: 105-123.

Hsu, T.C. (1983). Genetic instability in the human population: a working hypothesis. Hereditas 98: 1-9.

Hsu, T.C., Ramkissoon, D. and Furlong, C. (1986). Differential susceptibility to a mutagen among human individuals: synergistic effect on chromosome damage between bleomycin and aphidicolin. Anticancer Res. 6: 1171-1176.

Hsu, T.C., Shillitoe, E.F., Cherry, L.M., Li, Q., Schantz, S.P. and Furlong, C. (1990). Cytogenetic characterization of 20 lymphoblastoid lines derived from human individuals differing in bleomycin sensitivity. In Vitro Cell Dev. Biol. 26: 80-84.

Kripke, M.L. (1979). Speculation on the role of ultraviolet radiation in the development of malignant melanoma. JNCI 63: 541-548.

Kuo, M.T. and Hsu, T.C. (1978). Biochemical and cytological studies of bleomycin action on chromatin and chromosomes. Chromosoma 68 : 229-240.

Multani, A.S., Li, C., Ozen, M., Imam, S.A., Wallace, S. and Pathak, S. (1999a). Cell-killing by paclitaxel in a metastatic murine melanoma cell line is mediated by extensive telomere erosion with no decrease in telomerase activity. Oncol. Rep. 6: 39-44.

Multani, A.S., Ozen, M., Sen, S., Mandal, A.K., Price, J.E., Fan, D., Radinsky, R., Ali-Osman, F., von Eschenbach, A.C., Fidler, I.J. and Pathak, S. (1999b). Amplification of telomeric DNA directly correlates with metastatic potential of human and murine cancers of various histologic origin. Int. J. Oncol. 15: 423-429.

Nemeth, M.A., Wilson, M.R., Fidler, I.J. and Pathak, S. (1997). Increasing metastatic potential is associated with induced chromosome 14 translocations in a previously nonmetastatic murine melanoma cell line. Cancer Genet. Cytogenet. 98: 119-125.

Nowell, P.C. (1974). Diagnostic and prognostic value of chromosome studies in cancer. Ann. Clin. Lab. Sci. 4: 234-240.

Nowell, P.C. (1976). The clonal evolution of tumor cell population. Science 194: 23-28.

Nowell, P.C. (1986). Mechanisms of tumor progression. Cancer Res. 46: 2203-2207.

Pai, S.A., Cheung, M.-C.P., Romsdahl, M.M., Multani, A.S. and Pathak, S. (1999). Can genetic instability be studied at single chromosome level in cancer cells? Evidence from human melanoma cells. Cancer Genet. Cytogenet. 109: 51-57.

Paika, D.K. and Krishan, A. (1973). Bleomycin-induced chromosomal aberrations in cultured mammalian cells. Cancer Res. 33: 961-965.

Pathak, S. (1976). Chromosome banding techniques. J. Reprod. Med. 17: 25-28.

Pathak, S. (1990). Cytogenetic abnormalities in cancer: With special emphasis on tumor heterogeneity. Cancer Metastasis Rev. 8: 299-318.

Pathak, S., Staroselsky, A.H. and Fidler, I.J. (1991). Specific chromosomal defects associated with metastatic potential in K-1735 melanoma clones: Involvement of chromosomes 4 and 14. Cancer Genet. Cytogenet. 56: 209-221.

Pathak, S., Risin, S., Brown, N.M. and Berry, K. (1994a). Telomeric association of chromosomes is an early manifestation of programmed cell death. Int. J. Oncol. 4: 323-328.

Pathak, S., Dave, B.J. and Gagos, S.H. (1994b). Chromosome alterations in cancer development and apoptosis. In Vivo 8: 843-850.

Pathak, S., Dave, B.J. and Gadhia, P.K. (1995). Mouse chromosome 14 is altered in different metastatic murine neoplasias. Cancer Genet. Cytogenet. 83: 172-173.

Setlow, R.B. (1978). Repair deficient human disorders and cancer. Nature 271:713-717.

(Received July 19, 2000) 
